\title{
DIFFERENTIAL RESPONSES OF CERTAIN ETHIOPIAN GROUNDNUT (Arachis hypogaea L.) VARIETIES VARYING IN DROUGHT TOLERANCE, TO TERMINAL DROUGHT STRESS
}

\author{
P.R. Jeyaramraja ${ }^{1, *}$, Woldesenbet Fantahun ${ }^{2}$
}

${ }^{1}$ Department of Biology, College of Natural Sciences, Arba Minch University, Post Box No. 21, Arba Minch, Gamo Zone, Federal Democratic Republic of Ethiopia.

${ }^{2}$ Ethiopian Biotechnology Institute, Addis Ababa, Federal Democratic Republic of Ethiopia.

Received - February 05, 2020; Revision - March 21, 2020; Accepted - April 15, 2020

Available Online - April 25, 2020

DOI: http://dx.doi.org/10.18006/2020.8(2).185.192

KEYWORDS
Drought susceptibility
Drought tolerance
Peanut
Specific leaf mass
Water stress

\begin{abstract}
Responses of drought tolerant (DT) and drought susceptible (DS) Ethiopian groundnut varieties to terminal drought stress were compared to determine the traits behind drought tolerance. Drought (D) induced from 91 to 105 days after sowing (DAS) reduced leaf RWC (relative water content, \%), leaf area $\left(\mathrm{cm}^{2}\right.$ plant $\left.^{-1}\right)$, Chl (chlorophyll, $\mathrm{mg} \mathrm{g}^{-1}$ fresh weight), RDM (root dry mass, $\mathrm{g} \mathrm{plant}^{-1}$ ), ADM (aboveground dry mass, g plant $^{-1}$ ), TDM (total dry mass, $\mathrm{g}_{\text {plant }}{ }^{-1}$ ) and plant height $(\mathrm{cm})$; however, D increased SLM (specific leaf mass, $\mathrm{g} \mathrm{m}^{-2}$ ). High leaf RWC in DS types reinstated the hypothesis that capacity to save leaf water is not a method of drought tolerance. Although there were insignificant Chl differences between DT and DS types, dry matter accumulation (RDM and ADM) was higher in DT types, which is attributed to higher SLM in DT types. SLM had significant positive relationship with RDM. An increase in plant height without increase in leaf area explains drought susceptibility in DS types. Resumption of irrigation on 106 DAS resulted in an increase in leaf RWC; however, this accompanied no resurrection response in terms of studied physiological and growth parameters and thus, it was not possible to restore pod yield after D impaired groundnut growth. Certain parameters were higher in DT types, positively correlated with DRI (drought response index) and primarily decided by the genotype; such parameters were concluded to be the traits behind drought tolerance.
\end{abstract}

* Corresponding author

E-mail: prjeyaramraja@yahoo.co.in (P.R. Jeyaramraja)

Peer review under responsibility of Journal of Experimental Biology and Agricultural Sciences.

Production and Hosting by Horizon Publisher India [HPI] (http://www.horizonpublisherindia.in/).

All rights reserved.
All the articles published by Journal of Experimental Biology and Agricultural Sciences are licensed under a Creative Commons Attribution-NonCommercial 4.0 International License Based on a work at www.jebas.org.

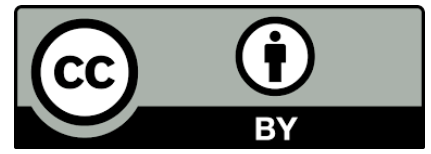




\section{Introduction}

Groundnut (Arachis hypogaea L.) is a significant crop plant utilized to produce foodstuff and cooking oil. Being a rain-fed crop (Nagaveni \& Khan, 2019), it generally undergoes D under field conditions that brings about reductions in crop yield. Besides, D is a predisposing factor for aflatoxin production in groundnut (Waliyar et al., 2003). D is a devastating physical stress and more challenging to the attempts of breeders (Tuberosa \& Salvi, 2006). Breeding drought tolerance in groundnuts cultivars would reduce yield losses due to D in rain-fed growing areas (Kakeeto et al., 2020). Breeding works to develop drought tolerance have been hampered in the past by its quantitative genetic base and by low understanding of the physiological base of productivity under D (Passioura, 2002). Hence, improvement of the current knowledge of reactions of crops to $\mathrm{D}$ and the methods contained in drought tolerance have turn out to be main goals of research and investment, with the crucial objective of producing crops with better WUE and reduced yield loss due to D (Somerville \& Briscoe, 2001; Zhang et al., 2004).

Plants notice and react quickly to little changes in water status through a series of physiological, cellular, and molecular events (Chaves et al., 2009). D can activate a range of plant reactions, which comprise reduction in leaf RWC and water potential (Lawlor \& Cornic, 2002), decrease in stomatal aperture and net photosynthetic rate. Photosynthesis is an important metabolism which is altered by $\mathrm{D}$ via reduced diffusion of $\mathrm{CO}_{2}$ to chloroplast and metabolic limitations (Pinheiro \& Chaves, 2011). Important assessments on crop reactions at large (Yordanov et al., 2000), and groundnut especially (Reddy et al., 2003), to D give additional knowledge on physiological features accompanying D. Nevertheless, there is even now no complete standard system for assessing drought tolerance, particularly since the physiological method is not all the time sufficient for selection on account of negative relationships between physiological attributes contained in drought adaptation (Turner et al., 2001). As a result, crop development plans have been unable to completely use current physiological data.

Responses of model plants namely, Arabidopsis and Craterostigma to D have been broadly studied (YamaguchiShinozaki et al., 1995; Shinozaki \& Yamaguchi-Shinozaki, 1996). Evaluation of the regulatory mechanisms of carbon assimilation in peanut due to forthcoming alterations in climate, including D, is inadequate (Clifford et al., 2000). Even though remarkable developments have been achieved regarding the type of actions happening in crops exposed to D, explanation of the metabolic regulation is even now absent (Rolland et al., 2006; Shinozaki \& Yamaguchi-Shinozaki, 2007). Jeyaramraja \& Thushara (2013) postulated a series of physiological reactions in peanut exposed to D. However, holistic studies in groundnut on the relationships among physiological, growth and yield parameters and their changes due to terminal $\mathrm{D}$ under natural field conditions are limited. As groundnut is mostly grown as rain-fed crop, it faces D during terminal stages of crop growth (Hampannavar \& Khan, 2019), which results in reductions in yield and quality. Hence, it is essential to produce crops that bear D. Knowledge of drought tolerance mechanisms in legumes innately adjusted to $\mathrm{D}$, such as groundnut, is essential in identifying markers for drought tolerance which in turn, can aid in plant breeding programmes. Nevertheless, little literature is available in groundnut on the physiological and growth parameters especially during the terminal stages of crop growth which is prone to D under field conditions i.e., from 90 to 110 DAS. Hence, the present study has been taken up.

Bacharou Falke et al. (2019) stated that investigation of groundnut genotypes response to drought stress could contribute to improving drought tolerance and productivity. Hence, in the present investigation, responses of DT and DS groundnut varieties during terminal stages of growth (90 to 110 DAS) was studied. This study was planned to investigate the consequence of $\mathrm{D}$ on certain physiological and growth parameters in Ethiopian groundnut varieties differing in drought tolerance, because it is assumed to be helpful in identifying traits behind tolerance/susceptibility to D.

\section{Materials and Methods}

The experiment was conducted inside "Natural Beauty Initiative Centre", Main Campus, Arba Minch University, Ethiopia during April to September 2014.

\subsection{Plant Material}

Pods of six groundnut varieties were collected from Werer Agricultural Research Centre during April 2014. Pod and seed characteristics of these varieties were published (Jeyaramraja \& Fantahun, 2014). These varieties were categorized into DT (ROBA, Werer 962, NC-4x) and DS (FAYO, Tole 2, Werer 964) types based on DRI values (Table 4) obtained from two growing seasons (Jeyaramraja \& Fantahun, 2016).

\subsection{Experimental Design}

The experimental design was Randomized Block Design (RBD) with three replications. There were 6 experimental plots for each variety ( 3 for $\mathrm{C}$ and 3 for D) and since totally 6 varieties were used in this study; there were totally 36 plots (18 for $\mathrm{C}$ and 18 for D). A buffer zone of $2 \mathrm{~m}$ was left between $\mathrm{C}$ and $\mathrm{D}$ plots to avoid diffusion of water through soil layers during D induction period from $\mathrm{C}$ to D plots. 


\subsection{Experimental Layout}

After ploughing the field three times into a fine tilth, experimental layout was made. Each plot had 4 numbers of $5 \mathrm{~m}$ ridges. Distance between two adjacent ridges was $60 \mathrm{~cm}$. Inter-row spacing between plants was $30 \mathrm{~cm}$ while intra-row spacing between plants was $10 \mathrm{~cm}$. Each plot was surrounded by bunds. Each plot had a length of $5 \mathrm{~m}$ and width of $3 \mathrm{~m}$. Hence, the size of one plot was 15 $\mathrm{m}^{2}$. The size of total experimental layout was $600 \mathrm{~m}^{2}$.

\subsection{Cultivation practices of groundnut}

The soil was loamy. Sowing was done manually on both sides of ridges at $\sim 4 \mathrm{~cm}$ depth. Sound, mature and good quality kernels were only selected for sowing. Kernels were subjected to treatment with Mancozeb (4 $\mathrm{g} \mathrm{kg}^{-1}$ kernels) to guard the juvenile seedlings from root-rot and collar-rot infection. Compost $\left(2 \mathrm{t} \mathrm{ha}^{-1}\right)$ was applied as basal dressing and incorporated well into the soil. Carbaryl 10 per cent DP was applied in soil at the time of seeding against ants/earwigs/termites.

\subsection{Induction of D under field conditions}

When groundnut is grown under field conditions as rain-fed crop, it does not experience D at all developmental stages. Jogloy et al. (1996) reported that groundnut generally experiences D during pegging and pod development and then may have sufficient quantity of water. This would cause severe decrease in yield, and the degree of decrease would rely on groundnut varieties (Kambiranda et al., 2011). Hence in the present study, D was induced by withholding irrigation in the field 91 DAS for a period of 15 days, i.e., up to 105 DAS, so that, simulated D could mimic the effects of naturally occurring D in the field. Rainout shelter which can cover the whole D plots was kept ready from 91 DAS to 105 DAS, so that, in the event of rainfall, the $\mathrm{D}$ plots could be covered immediately.

\subsection{Irrigation Schedule}

On the day of sowing seeds and 1 DAS, the field was irrigated. Then, irrigation was usually given once a week (i.e., 8 DAS, 15 DAS, 22 DAS and so on) based on soil water measured at four places ( 2 in C plots; 2 in D plots) with the help of a tensiometer. When water potential of top soil reaches -0.25 to -0.50 bars, irrigation was provided. Irrigation was skipped if rainfall replenished soil water. For $\mathrm{C}$ plots, irrigation continued until a week before harvest maturity of each variety. For D plots, the irrigation was skipped two times i.e., at 92 DAS and 99 DAS to induce D. It has to be noted that there was no rainfall in the field from 91 DAS to 105 DAS i.e., during the D induction period and hence, rainout shelter was not used to protect the D plots from rain. From 106 DAS, water supply was resumed for D plots and was continued until a week before harvest maturity of each variety.

\subsection{Physiological and growth parameters}

From each variety that is under C (or) D conditions, one plant was chosen randomly from each plot for analysis of below-given parameters which were measured 5 times (i.e., 90 DAS, 95 DAS, 100 DAS, 105 DAS \& 110 DAS).

\subsubsection{Plant water status}

RWC was measured in the third leaf from the top of the main shoot as said by Clavel et al. (2006) employing the equation: RWC = $[(\mathrm{FM}-\mathrm{DM}) /(\mathrm{TM}-\mathrm{DM})] \times 100$, where $\mathrm{FM}$ was fresh leaf mass, TM was turgid mass after 4-h rehydration of the leaf in distilled water at room temperature under dark conditions, and DM was dry mass after drying at $85^{\circ} \mathrm{C}$ for $24 \mathrm{~h}$.

\subsubsection{Pigment estimation}

Chl was determined spectrophotometrically as per the method of Sadasivam \& Manickam (1996) in the second leaf from the top of main shoot.

\subsubsection{Growth parameters}

RDM, ADM \& TDM were determined in line with Clavel et al. (2005). Plants were cautiously isolated from the soil and the roots were cleaned with water. Afterwards, RDM and ADM were determined after drying at $80^{\circ} \mathrm{C}$ for 2 days. TDM is the sum of $\mathrm{ADM}$ and RDM. Leaf area was determined by a non-destructive method employing allometric model (Kathirvelan \& Kalaiselvan, 2007). In the third leaf from the top of main shoot, SLM was obtained (Clavel et al., 2005), which is the ratio of leaf dry mass per unit leaf area. Plant height was determined with a ruler from the ground to top of the main axis.

\subsection{Statistical analysis}

Three factor ANOVA was carried out for the analysis of physiological and growth parameters wherein Factor A is varieties (6), Factor B is treatments (2 - C and D) and Factor C is DAS (5 90 DAS, 95 DAS, 100 DAS, 105 DAS and 110 DAS). Critical difference $(\mathrm{CD})$ values were computed at 0.05 and 0.01 levels to find out whether statistically significant differences existed within varieties, treatments, and/ DAS. Interactions between the factors were also studied. Correlation coefficients among various physiological and growth parameters were studied to find out relationships among them.

\section{Results and Discussion}

To compare the effects of $\mathrm{C}$ and $\mathrm{D}$ on moisture content of groundnut leaves, RWC was used in the present investigation because it is thought to be a helpful integrator of crop water balance than leaf water potential (Wright \& Nageswara Rao, 1994). Significant 
variations were found among the groundnut varieties in terms of studied physiological and growth parameters except leaf area plant ${ }^{-1}$ and Chl (Table 1). The fact that DS types had high leaf RWC in this work is of interest. DT Phaseolus vulgaris frequently open their stomata under harsh D (Costa França et al., 2000). DS cultivar had at all times high RWC mainly up to 35 days of D on two-week-old groundnut seedlings (Clavel et al., 2005). Above quoted earlier works and the present study reconfirmed the hypothesis proposed by Jeyaramraja \& Thushara (2013) that capacity to save water in groundnut leaf is not a method of drought tolerance. Vadez (2014) also said that water saving mechanisms should not be considered as mechanisms of drought tolerance.

Although leaf RWC was higher in DS types (Table 1), Chl was the same in both DT and DS types. Kicheva et al. (1994) stated that reduction in rate of photosynthesis could happen owing to reduction in $\mathrm{Chl}$ under harsh $\mathrm{D}$. Hence, same contents of $\mathrm{Chl}$ observed in this work must lead to same rates of photosynthesis in DT and DS types and so, same rates of dry matter production. However, RDM and ADM were higher in DT types. The reason for higher dry matter production in DT types is attributed to higher SLM values in DT types. It is imperative to note here that the DT types had 1.23-fold more SLM as compared to DS types.

Like leaf RWC, plant height was also higher in DS types. Leaf RWC showed positive correlation with plant height irrespective of DAS ( $r$ $=0.38, \mathrm{p}<0.05, \mathrm{n}=36$ ). It must be noted here that leaf area did not vary between DT and DS types (Table 1); hence, just an increase in plant height without increase in leaf area would not help DS types to be productive, which thus resulted in insignificant correlation between these traits with $r$ value of -0.067 . Reduction in plant height with almost unchanged total biomass accumulation but with increased grain yield/harvest index was achieved in certain breeding experiments (Cattivelli et al., 1994; Slafer et al., 1994).

Drought is significantly $(\mathrm{p}<0.01)$ reduced leaf $\mathrm{RWC}$, leaf area plant ', Chl, RDM, ADM, TDM and plant height (Table 1). SLM was significantly $(\mathrm{p}<0.01)$ increased due to $\mathrm{D}$. The RWC reduction in plants under $\mathrm{D}$ could be related with reduction in crop vigour (Lopez et al., 2002; Halder \& Burrage, 2003). Stomatal regulation of water loss has been identified (Chaves, 1991) as an initial reaction for conditioning the leaf water status of field crops, but it rigorously reduces carbon uptake and biomass production and hence, there was reduction in RDM, ADM and TDM in the present study.

Although DS types had significantly high leaf RWC than DT types under C conditions, the leaf RWC of DT types was almost equal to that of DS types under D conditions (Table 1). As compared to C, D caused $4.8 \%$ reduction in leaf RWC in DS types whereas in DT types, it caused only $3 \%$ reduction. Both under $\mathrm{C}$ and $\mathrm{D}$ conditions, DT types had significantly higher RDM than DS types. Higher RDM values in DT types may be attributed to deeper root system for soil moisture capture which is a successful method of attaining reproductive success under D (Kirkegaard et al., 2007). High dry matter production in DT cultivars under field conditions is caused by more capability to keep up transpiration, which is aided by deep roots (Blum, 2009). In a study in groundnut profuse root system in the deep soil was related to better yield under D and it was deduced that greater, lengthy and denser roots at deep soil was accountable for more water absorption (Jongrungklang et al., 2012). Although insignificant difference was found between DT and DS types regarding ADM and TDM under C conditions, DT types maintained significantly higher $\mathrm{ADM}$ and TDM than DS types under D conditions. D caused just 9.6 \% ADM reduction in DT types while in DS types, it caused a tremendous reduction of $19.7 \%$ (Table 1).

Because the plants in C and D plots were approaching maturity and in addition, the plants in D plots suffer D from 91 DAS, leaf RWC was found to decline significantly and progressively from 90 to 105 DAS (Table 2). However, due to resumption of irrigation on 106 DAS, leaf RWC could significantly $(\mathrm{p}<0.05)$ increase on 110 DAS in D plots. Although significant decrease in leaf area plant ${ }^{-1}$ was observed from 90 DAS, the decrease was irregular (Table 2). Besides, due to resumption of irrigation on 106 DAS, leaf area plant $^{-1}$ could not increase significantly on 110 DAS in D plots. Chl was also found to decrease significantly from 90 to 105 DAS; however, Chl could not increase significantly on 110 DAS in D plots. RDM, ADM and TDM were on the decreasing trend significantly from 90 to 105 DAS. No resurrection response was found on 110 DAS in terms of RDM, ADM and TDM in D plots. Although statistically insignificant, SLM was found to increase from 90 DAS. Plant height had increased significantly from 90 to 105 DAS and there was statistically insignificant increase in plant height on 110 DAS in D plots.

As D was induced from 91 DAS, there were no significant differences between $\mathrm{C}$ and D plots on 90 DAS with respect to the studied physiological and growth parameters (Table 2). Leaf RWC was found to decrease both in $\mathrm{C}$ and D plots as the DAS increased. Reduction of leaf RWC in C plots was since the groundnut varieties were approaching maturity while in $\mathrm{D}$ plots, the reduction in leaf RWC was due to both reasons namely, D and approaching maturity. It is imperative to note here that the reduction of leaf RWC in D plots was more pronounced than in C plots until 105 DAS. Due to resumption of irrigation on 106 DAS, the leaf RWC could significantly revive on 110 DAS in D plots. RDM, ADM and TDM did not change significantly in C plots as DAS increased; however, these parameters decreased significantly in D plots until 105 DAS. No resurrection response in terms of RDM, ADM and TDM was observed on 110 DAS in D plots due to resumption of irrigation on 106 DAS. Plant height significantly increased in C plots with an increase in DAS; however, in D plots, there was no such increase in plant height (Table 2). 
Table 1 Effect of drought stress on physiological and growth parameters of certain Ethiopian groundnut varieties

\begin{tabular}{|c|c|c|c|c|c|c|c|c|c|c|c|c|c|c|c|c|}
\hline \multirow[t]{2}{*}{ Variety } & \multicolumn{2}{|c|}{$\begin{array}{c}\text { Leaf RWC } \\
(\%)\end{array}$} & \multicolumn{2}{|c|}{$\begin{array}{l}\text { Leaf area } \\
\left(\mathrm{cm}^{2} \text { plant }\right.\end{array}$} & \multicolumn{2}{|c|}{$\begin{array}{c}\text { Chl } \\
\left(\mathrm{mg} \mathrm{g}^{-1} \mathrm{FW}\right)\end{array}$} & \multicolumn{2}{|c|}{$\begin{array}{c}\text { RDM } \\
\left(\text { g plant }^{-1}\right)\end{array}$} & \multicolumn{2}{|c|}{$\begin{array}{c}\mathrm{ADM} \\
\left(\mathrm{g} \mathrm{plant}^{-1}\right)\end{array}$} & \multicolumn{2}{|c|}{$\begin{array}{c}\text { TDM } \\
\left(\mathrm{g} \mathrm{plant}^{-1}\right)\end{array}$} & \multicolumn{2}{|c|}{$\begin{array}{c}\text { SLM } \\
\left(\mathrm{g} \mathrm{m}^{-2}\right)\end{array}$} & \multicolumn{2}{|c|}{$\begin{array}{l}\text { Plant height } \\
(\mathrm{cm})\end{array}$} \\
\hline & $\mathrm{C}$ & $\mathrm{D}$ & $\mathrm{C}$ & $\mathrm{D}$ & $\mathrm{C}$ & $\mathrm{D}$ & $\mathrm{C}$ & $\mathrm{D}$ & $\mathrm{C}$ & $\mathrm{D}$ & $\mathrm{C}$ & $\mathrm{D}$ & $\mathrm{C}$ & $\mathrm{D}$ & $\mathrm{C}$ & $\mathrm{D}$ \\
\hline \multicolumn{17}{|c|}{ Drought Tolerant } \\
\hline ROBA & 80.3 & 76.5 & 229.9 & 218.3 & 2.57 & 2.52 & 3.22 & 3.22 & 19.61 & 17.53 & 22.83 & 20.74 & 67.3 & 69.1 & 37.4 & 33.9 \\
\hline Werer 962 & 79.5 & 78.4 & 223.9 & 210.9 & 2.75 & 2.56 & 3.48 & 3.26 & 19.07 & 17.30 & 22.55 & 20.56 & 65.1 & 66.3 & 36.1 & 33.3 \\
\hline $\mathrm{NC}-4 \mathrm{x}$ & 80.2 & 77.8 & 208.2 & 219.4 & 2.67 & 2.46 & 3.43 & 3.18 & 18.81 & 17.12 & 22.25 & 20.30 & 62.5 & 64.4 & 47.9 & 46.3 \\
\hline Mean (DT) & 80.0 & 77.6 & 220.7 & 216.2 & 2.67 & 2.51 & 3.38 & 3.22 & 19.16 & 17.32 & 22.54 & 20.54 & 64.9 & 66.6 & 40.5 & 37.8 \\
\hline \multicolumn{17}{|c|}{ Drought Susceptible } \\
\hline FAYO & 82.4 & 77.1 & 236.3 & 229.3 & 2.67 & 2.46 & 3.27 & 3.03 & 19.35 & 15.51 & 22.62 & 18.54 & 61.5 & 62.4 & 45.5 & 43.7 \\
\hline Tole 2 & 82.2 & 78.3 & 220.2 & 209.6 & 2.59 & 2.36 & 3.27 & 3.02 & 19.62 & 16.25 & 22.89 & 19.27 & 52.7 & 54.2 & 49.2 & 47.2 \\
\hline Werer 964 & 79.8 & 77.2 & 214.0 & 217.4 & 2.54 & 2.40 & 3.01 & 2.82 & 18.41 & 14.35 & 21.42 & 17.17 & 44.5 & 46.7 & 44.7 & 40.5 \\
\hline Mean (DS) & 81.4 & 77.5 & 223.5 & 218.7 & 2.60 & 2.41 & 3.18 & 2.96 & 19.13 & 15.37 & 22.31 & 18.33 & 52.9 & 54.4 & 46.4 & 43.8 \\
\hline \multicolumn{17}{|c|}{ Statistical significance } \\
\hline \multicolumn{17}{|l|}{$C D 5 \%$} \\
\hline between varieties & \multicolumn{2}{|c|}{0.73} & \multicolumn{2}{|c|}{ NS } & \multicolumn{2}{|c|}{ NS } & \multicolumn{2}{|c|}{0.09} & \multicolumn{2}{|c|}{0.37} & \multicolumn{2}{|c|}{0.38} & \multicolumn{2}{|c|}{2.1} & \multicolumn{2}{|c|}{1.2} \\
\hline between treatments & \multicolumn{2}{|c|}{0.42} & \multicolumn{2}{|c|}{11.6} & \multicolumn{2}{|c|}{0.08} & \multicolumn{2}{|c|}{0.05} & \multicolumn{2}{|c|}{0.21} & \multicolumn{2}{|c|}{0.22} & \multicolumn{2}{|c|}{1.2} & \multicolumn{2}{|c|}{0.7} \\
\hline variety $X$ treatment & \multicolumn{2}{|c|}{1.03} & \multicolumn{2}{|c|}{ NS } & \multicolumn{2}{|c|}{ NS } & 0 . & & & & 0 . & 54 & & & & $\mathrm{~S}$ \\
\hline
\end{tabular}

Values are irrespective of DAS ie., averages of five various days after sowing $(90,95,100,105 \& 110$ DAS)

Table 2 Effect of drought stress on physiological and growth parameters in groundnut at various days after sowing

\begin{tabular}{|c|c|c|c|c|c|c|c|c|c|c|c|c|c|c|c|c|}
\hline \multirow[t]{2}{*}{ DAS } & \multicolumn{2}{|c|}{$\begin{array}{l}\text { Leaf RWC } \\
(\%)\end{array}$} & \multicolumn{2}{|c|}{$\begin{array}{c}\text { Leaf area } \\
\left(\mathrm{cm}^{2} \text { plant }^{-1}\right)\end{array}$} & \multicolumn{2}{|c|}{$\begin{array}{c}\mathrm{Chl} \\
\left(\mathrm{mg} \mathrm{g}^{-1} \mathrm{FW}\right)\end{array}$} & \multicolumn{2}{|c|}{$\begin{array}{c}\text { RDM } \\
\left(\text { g plant }^{-1}\right)\end{array}$} & \multicolumn{2}{|c|}{$\begin{array}{c}\mathrm{ADM} \\
\left(\mathrm{g}_{\text {plant }}{ }^{-1}\right)\end{array}$} & \multicolumn{2}{|c|}{$\begin{array}{c}\text { TDM } \\
\left(\text { g plant }^{-1}\right)\end{array}$} & \multicolumn{2}{|c|}{$\begin{array}{c}\text { SLM } \\
\left(\mathrm{g} \mathrm{m}^{-2}\right)\end{array}$} & \multicolumn{2}{|c|}{$\begin{array}{l}\text { Plant height } \\
\quad(\mathrm{cm})\end{array}$} \\
\hline & $\mathrm{C}$ & $\mathrm{D}$ & $\mathrm{C}$ & $\mathrm{D}$ & $\mathrm{C}$ & $\mathrm{D}$ & $\mathrm{C}$ & $\mathrm{D}$ & $\mathrm{C}$ & $\mathrm{D}$ & $\mathrm{C}$ & $\mathrm{D}$ & $\mathrm{C}$ & $\mathrm{D}$ & $\mathrm{C}$ & $\mathrm{D}$ \\
\hline 90 DAS & 82.2 & 81.9 & 257.5 & 257.9 & 2.72 & 2.73 & 3.28 & 3.30 & 19.37 & 19.64 & 22.64 & 22.93 & 58.4 & 59.3 & 40.0 & 39.9 \\
\hline 95 DAS & 81.8 & 79.2 & 218.0 & 172.4 & 2.63 & 2.43 & 3.28 & 3.18 & 17.95 & 17.39 & 21.23 & 20.57 & 58.9 & 59.4 & 41.5 & 40.8 \\
\hline $100 \mathrm{DAS}$ & 80.5 & 76.6 & 216.1 & 229.7 & 2.64 & 2.43 & 3.30 & 3.04 & 19.17 & 16.69 & 22.47 & 19.73 & 58.8 & 60.6 & 43.5 & 41.2 \\
\hline 105 DAS & 80.0 & 73.9 & 216.4 & 207.4 & 2.58 & 2.35 & 3.28 & 2.94 & 19.61 & 14.07 & 22.89 & 17.01 & 59.2 & 61.8 & 45.5 & 41.0 \\
\hline $110 \mathrm{DAS}$ & 79.2 & 76.0 & 202.4 & 219.9 & 2.59 & 2.37 & 3.26 & 2.99 & 19.63 & 13.92 & 22.89 & 16.91 & 59.3 & 61.5 & 46.8 & 41.2 \\
\hline \multicolumn{17}{|l|}{$\begin{array}{c}\text { Statistical } \\
\text { significance }\end{array}$} \\
\hline \multicolumn{17}{|l|}{$C D 5 \%$} \\
\hline between DAS & \multicolumn{2}{|c|}{0.67} & \multicolumn{2}{|c|}{18.3} & \multicolumn{2}{|c|}{0.12} & \multicolumn{2}{|c|}{0.08} & \multicolumn{2}{|c|}{0.33} & \multicolumn{2}{|c|}{0.35} & \multicolumn{2}{|c|}{ NS } & \multicolumn{2}{|c|}{1.1} \\
\hline $\begin{array}{l}\text { treatment } X \\
\text { DAS }\end{array}$ & \multicolumn{2}{|c|}{0.94} & \multicolumn{2}{|c|}{25.9} & \multicolumn{2}{|c|}{ NS } & \multicolumn{2}{|c|}{0.11} & \multicolumn{2}{|c|}{0.47} & \multicolumn{2}{|c|}{0.49} & \multicolumn{2}{|c|}{ NS } & \multicolumn{2}{|c|}{1.6} \\
\hline
\end{tabular}

Values are irrespective of varieties ie., averages of six varieties.

Proportion of variation due to stress treatments is more with regard activity of the mesophyll under unit area of leaf (Jun \& Imai, 1999). to leaf RWC, leaf area plant ${ }^{-1}, \mathrm{Chl}$, RDM, ADM and TDM (Table 3). Hence, higher values of SLM in DT types observed in this work On the other hand, proportion of variation due to variety is more might lead to an increase in leaf thickness (mesophyll mass and followed by stress treatments and DAS regarding SLM and plant activity) and thereby, an increase in photosynthetic activity and dry height. SLM is not developmentally controlled; but environmentally matter production. It is imperative to note here that SLM had strong (by D) and, genetically controlled. SLM is an index of mass and positive relationship with $\mathrm{RDM}(\mathrm{r}=0.612, \mathrm{p}<0.001, \mathrm{n}=36)$ based on 
Table 3 Mean squares in the three factor analysis of variance for physiological and growth parameters measured on certain groundnut varieties of Ethiopia

\begin{tabular}{|c|c|c|c|c|c|c|c|c|c|}
\hline \multirow[t]{2}{*}{ Source of variation } & \multirow[t]{2}{*}{ d.f. } & \multicolumn{8}{|c|}{ Mean squares } \\
\hline & & RWC (\%) & $\begin{array}{l}\text { Leaf area } \\
\left(\mathrm{cm}^{2} \text { plant }\right.\end{array}$ & $\begin{array}{c}\text { Chl mg g }{ }^{-1} \\
\text { FW }\end{array}$ & $\underset{\left(\text { g plant }^{-1}\right)}{\mathrm{RDM}}$ & $\underset{\left(\mathrm{g}_{\text {plant }}{ }^{-1}\right)}{\mathrm{ADM}}$ & $\begin{array}{c}\text { TDM } \\
\left(\mathrm{g} \mathrm{plant}^{-1}\right)\end{array}$ & $\begin{array}{l}\text { SLM } \\
\mathrm{g} \mathrm{m}^{-2}\end{array}$ & $\begin{array}{l}\text { Plant height } \\
\quad(\mathrm{cm})\end{array}$ \\
\hline Factor A (variety) & 5 & $14.68 * *$ & 1087.71 & 0.14 & $0.75^{* *}$ & $17.55^{* *}$ & $24.34 * *$ & $2191.89 * *$ & $983.78 * *$ \\
\hline Factor B (treatments) & 1 & $459.26^{* *}$ & $12384.08^{* *}$ & $1.33 * *$ & $1.64 * *$ & $353.58^{* *}$ & $403.35^{* *}$ & $116.22 * *$ & $314.94 * *$ \\
\hline Factor C (DAS) & 4 & $161.53 * *$ & $6842.38^{* *}$ & $0.38 * *$ & $0.20 * *$ & $43.96 * *$ & $49.50^{* *}$ & 20.42 & $92.74 * *$ \\
\hline Interaction (A X B) & 5 & $15.55^{* *}$ & 1234.13 & 0.04 & $0.07 *$ & $8.73 * *$ & $9.13 * *$ & 1.39 & 8.13 \\
\hline Interaction (A X C) & 20 & 1.18 & 1371.43 & 0.01 & 0.01 & $2.28 * *$ & $2.29 * *$ & 2.13 & 1.34 \\
\hline Interaction (B X C) & 4 & $40.05^{* *}$ & $10799.80^{* *}$ & 0.10 & $0.20 * *$ & $68.52 * *$ & $75.34 * *$ & 7.41 & $51.31 * *$ \\
\hline Interaction (A X B X C) & 20 & 0.64 & 1288.13 & 0.01 & 0.01 & $1.45^{* *}$ & $1.56^{* *}$ & 0.93 & 0.75 \\
\hline Error & 118 & 2.09 & 1575.23 & 0.07 & 0.03 & 0.52 & 0.57 & 16.41 & 5.73 \\
\hline CV (\%) & & 1.83 & 18.50 & 10.40 & 5.31 & 4.07 & 3.60 & 6.79 & 5.68 \\
\hline * significance at $\mathrm{p}<0.05$ & & & & & & & & & \\
\hline$* *$ significance at $\mathrm{p}<0.01$ & & & & & & & & & \\
\hline
\end{tabular}
treatments ( 2 namely $\mathrm{C}$ and $\mathrm{D}$ ). Factor $\mathrm{C}$ is days after sowing (5 namely 90 DAS, 95 DAS, 100 DAS, 105 DAS and 110 DAS).

Table 4 Linear regression analysis giving the relationships of DRI values obtained in a previous study on the same groundnut varieties (Jeyaramraja \& Fantahun, 2016) with few studied parameters in the present study. Relationships are given by the formula $\mathrm{y}=\mathrm{a}+\mathrm{bx} .{ }^{*} \mathrm{p}<0.05 ; * * \mathrm{p}<0.01$. $\mathrm{y}$ - dependent variable (DRI); $\mathrm{x}$ - independent variable (Traits of drought tolerance); R - correlation coefficient; a, b - constants.

\begin{tabular}{|lcccc|}
$\mathrm{X}$ & $\mathrm{R}$ & $\mathrm{R}^{2}$ & $\mathrm{a}$ & $\mathrm{b}$ \\
\hline $\mathrm{SLM}$ & $0.917^{* *}$ & 0.841 & 16.92 & 62.34 \\
\hline SLM/RWC & $0.935^{* *}$ & 0.875 & 0.195 & 0.815 \\
\hline SLM/RDM & $0.937^{* *}$ & 0.879 & 8.373 & 15.03 \\
\hline SLM/ADM & $0.884^{*}$ & 0.782 & 1.541 & 2.643 \\
\hline SLM/Plant height & $0.888^{*}$ & 0.789 & -0.338 & 2.610 \\
\hline ADM/RWC & $0.875^{*}$ & 0.765 & 0.177 & 0.068 \\
\hline
\end{tabular}

data irrespective of DAS. From the significant interactions between variety and stress treatments (Table 3), it can be inferred that there is genotype-specific D response in terms of leaf RWC, RDM, ADM and TDM. From the significant interactions between variety and DAS, it can be concluded that each variety responds differently to various DAS in terms of ADM and TDM (due to differences in days to maturity). Significant interactions between stress treatments and DAS were also noted, which suggest that $\mathrm{D}$ has different effects at various DAS in terms of leaf RWC, leaf area plant $^{-1}, \mathrm{RDM}, \mathrm{ADM}$, TDM and plant height. Low total transpiration to control water loss, chlorophyll content, and root length density revealed drought tolerance associated traits for pod production in groundnut, according to Bacharou Falke et al. (2019). Savita et al. (2019) reported that RWC at 75 DAS, SLM at 45 DAS and SPAD chlorophyll meter reading showed significant positive association with pod yield.

\section{Conclusions}

DT types registered high RDM, ADM, TDM and SLM; nevertheless, these traits could not be the traits of drought tolerance because except SLM, traits like RDM, ADM and TDM had insignificant relationships with DRI values obtained in a previous study on the same groundnut varieties. However, SLM showed significant $(\mathrm{p}<0.01)$ positive relationship with DRI. In addition, only SLM is decided primarily by the genotype/variety and hence, it is genetically controlled. This strengthens the hypothesis that drought tolerance is conferred by a mixture of many different traits at the genetic level and hence, SLM must be a marker for drought tolerance in groundnut.

In addition, we found that the ratios of SLM/RWC, SLM/RDM, SLM/ADM, SLM/Plant height, ADM/RWC had significant positive relationships with DRI and so, these ratios can be used as traits to identify drought tolerant varieties of groundnut in plant breeding/improvement programmes. DS types had significantly higher leaf RWC and plant height that are insignificantly related to DRI with $r$ values of -0.451 and -0.628 respectively. Since only plant height is primarily decided by the genotype/variety, it may be a marker for drought susceptibility. 


\section{Abbreviations}

$\mathrm{ADM}$ - aboveground dry mass; $\mathrm{C}$ - control, irrigated plants; $\mathrm{CD}$ critical difference; Chl - chlorophyll; D - drought; DAS - days after sowing; DRI - drought response index; DS - droughtsusceptible; DT - drought-tolerant; RDM - root dry mass; RWC leaf relative water content; SLM - specific leaf mass; TDM - total dry mass

\section{Acknowledgements}

Financial support for this whole study by Arba Minch University (GOV /AMU /TH14/CNS /BIOL /01/06) is gratefully acknowledged. The authors thank Werer Agricultural Research Centre for providing the groundnut seeds.

\section{Conflict of interest}

Both the authors declare that there is no conflict of interest.

\section{References}

Bacharou Falke A, Hamidou F, Halilou O, Harou A (2019) Assessment of groundnut elite lines under drought conditions and selection of tolerance associated traits. Advances in Agriculture Article ID 3034278, DOI: https://doi.org/10.1155/2019/3034278.

Blum A (2009) Effective use of water (EUW) and not water-use efficiency (WUE) is the target of crop yield improvement under drought stress. Field Crops Research 112: 119-123.

Cattivelli L, Delogu G, Terzi V, Stanca AM (1994) Progress in barley breeding. In: Slafer GA (Ed). Genetic Improvement of Field Crops, New York: Marcel Dekker Inc Pp. 95-181.

Chaves MM (1991) Effects of water deficits on C assimilation. Journal of Experimental Botany 42: 1-16.

Chaves MM, Flexas J, Pinheiro C (2009) Photosynthesis under drought and salt stress: regulation mechanisms from whole plant to cell. Annals of Botany 103: 551-560.

Clavel D, Diouf C, Khalfaoui JL, Braconnier S (2006) Genotypes variations in fluorescence parameters among closely related groundnut (Arachis hypogaea L.) lines and their potential for drought screening programs. Field Crops Research 96: 296-306.

Clavel D, Drame NK, Roy-Macauley H, Braconnier S, Laffray D (2005) Analysis of early responses to drought associated with field drought adaptation in four Sahelian groundnut (Arachis hypogaea L.) cultivars. Environmental and Experimental Botany 54: 219-230.

Clifford SC, Stronach IM, Black CR, Singleton-Jones PR, AzamAli SN, Crout NMJ (2000) Effects of elevated $\mathrm{CO}_{2}$, drought and temperature on the water relations and gas exchange of groundnut (Arachis hypogaea) stands grown in controlled environment glasshouses. Physiologia Plantarum 110: 78-88.

Costa Franca MG, Pham Thi AT, Pimentel C, Pereyra Rossiello RO, Zuily-Fodil Y, Laffray D (2000) Differences in growth and water relation among Phaseolus vulgaris cultivars in response to induced drought stress. Environmental and Experimental Botany 43: 227-337.

Halder KP, Burrage SW (2003) Drought stress effects on water relations of rice grown in nutrient film technique. Pakistan Journal of Biological Sciences 6: 441-444.

Hampannavar MR, Khan H (2019) Association study of morphological and physiological traits with yield in groundnut genotypes under terminal drought condition. International Journal of Current Microbiology and Applied Sciences 8: 668-678.

Jeyaramraja PR, Fantahun W (2014) Characterization of yield Components in certain groundnut (Arachis hypogaea L.) varieties of Ethiopia. Journal of Experimental Biology and Agricultural Sciences 2: 592-596.

Jeyaramraja PR, Fantahun W (2016) Influence of drought at podfilling stage on yield and yield components of groundnut (Arachis hypogaea L.) varieties of Ethiopia. Tropical Agriculture (Trinidad) 93: 235-244.

Jeyaramraja PR, Thushara SS (2013) Sequence of physiological responses in groundnut (Arachis hypogaea L.) subjected to soil moisture deficit. Photosynthetica 51: 395-403.

Jogloy S, Patanothai A, Toomsan S, Isleib TG (1996) Breeding peanut to fit into Thai cropping systems. In Proceedings of the Peanut Collaborative Research Support Program-International Research Symposium and Workshop, Two Jima Quality Inn, Arlington, Virginia, USA. 25-31 March 1996. Pp. 353-362.

Jongrungklang N, Toomsan B, Vorasoot N, Jogloy S, Boote KJ, Hoogenboom G, Patanothai A (2012) Classification of root distribution patterns and their contributions to yield in peanut genotypes under mid-season drought stress. Field Crops Research 127: 181-190.

Jun H, Imai K (1999) Cultivar differences of photosynthesis and respiration in peanut leaves. Bulletin of the Faculty of Agriculture, Meiji University 119: 21-25.

Kakeeto R, Melis R, Biruma M, Sibiya J (2020) Gene action governing the inheritance of drought tolerance and selected agronomic traits in Ugandan groundnut (Arachis hypogaea L.) lines under drought environment. Euphytica 216: 1. 
Kambiranda DM, Vasanthaiah HKN, Katam R, Ananga A, Basha SM, Naik K (2011) Impact of Drought Stress on Peanut (Arachis hypogaea L.) Productivity and Food Safety. In Vasanthaiah HKN, Kambiranda DM (Eds). Plants and Environment, InTech Pp. 249-272.

Kathirvelan P, Kalaiselvan P (2007) Groundnut (Arachis hypogaea L.) leaf area estimation using allometric model. Research Journal of Agriculture and Biological Sciences 3: 59-61.

Kicheva ML, Tsonev TD, Popova LP (1994) Stomatal and nonstomatal limitation of photosynthesis in two wheat cultivars subjected to water stress. Photosynthetica 30: 107- 116.

Kirkegaard JA, Lilley JM, Howe GN, Graham JM (2007) Impact of subsoil water use on wheat yield. Australian Journal of Agricultural Research 58: 303-315.

Lawlor DW, Cornic G (2002) Photosynthetic carbon assimilation and associated metabolism in relation to water deficits in higher plants. Plant, Cell \& Environment 25: 275-294.

Lopez CML, Takahashi H, Yamazaki S (2002) Plant water relations of Kidney bean plants treated with $\mathrm{NaCl}$ and foliarly applied glycine betaine. Journal of Agronomy and Crop Science 188: 73-80.

Nagaveni K, Khan H (2019) Genetic variability studies in terminal drought tolerant groundnut (Arachis hypogaea L.). Journal of Pharmacognosy and Phytochemistry 8: 747-750.

Passioura JB (2002) Environmental biology and crop improvement. Functional Plant Biology 29: 537-546.

Pinheiro C, Chaves MM (2011) Photosynthesis and drought: can we make metabolic connections from available data? Journal of Experimental Botany 62: 869-882.

Reddy TY, Reddy VR, Anbumozhi V (2003) Physiological responses of groundnut (Arachis hypogea L.) to drought stress and its amelioration: a critical review. Plant Growth Regulation 41: 75-88.

Rolland F, Baena-Gonzalez E, Sheen J (2006) Sugar sensing and signaling in plants: conserved and novel mechanisms. Annual Review of Plant Biology 57: 675-709.

Sadasivam S, Manickam A (1996) Biochemical Methods: $2^{\text {nd }}$ Edition. New Age Int Limited Publishers, Tamil Nadu Agricultural University, Coimbatore.

Savita SK, Kenchangoudar PV, Mamata SK, Rajashree B, Nadaf HL, Deshpande SK (2019) Studies on variability and genetic association of drought and yield related traits in advance breeding lines of groundnut (Arachis hypogaea L.). Journal of Pharmacognosy and Phytochemistry 8: 2145-2148.

Shinozaki K, Yamaguchi-Shinozaki K (1996) Molecular responses to drought and cold stress. Current Opinion in Biotechnology 7: 161-167.

Shinozaki K, Yamaguchi-Shinozaki K (2007) Gene networks involved in drought stress response and tolerance. Journal of Experimental Botany 58: 221-227.

Slafer GA, Satorre EH, Andrade H (1994) Increases in grain yield in bread wheat from breeding and associated physiological changes. In Slafer GA (Ed). Genetic Improvement of Field Crops, Marcel Dekker Inc., New York Pp. 1-67.

Somerville C, Briscoe J (2001) Genetic engineering and water. Science 292: 2217.

Tuberosa R, Salvi S (2006) Genomics-based approaches to improve drought tolerance of crops. Trends in Plant Science 11: 405-412.

Turner NC, Wright GC, Siddique KHM (2001) Adaptation of grain legume (pulses) to water-limited environments. Advances in Agronomy 71: 193-231.

Vadez V (2014) Root hydraulics:The forgotten side of roots in drought adaptation. Field Crops Research 165: 15-24.

Waliyar F, Reddy SV, Subramaniam K, Reddy TY, Krama D, Craufurd PQ, Wheeler TR (2003) Importance of mycotoxins in food and feed in India. Aspects of Applied Biology 68: 1-8.

Wright GC, Nageswara Rao RC (1994) Groundnut Water Relations. In Smartt JT (Ed). The Groundnut Crop, Springer, Dordrecht Pp. 281- 335.

Yamaguchi-Shinozaki K, Urao T, Shinozaki K (1995) Regulation of genes that are induced by drought stress in Arabidopsis thaliana. Journal of Plant Research 108: 127-136.

Yordanov I, Velikova V, Tsonev T (2000) Plant Responses to drought, acclimation, and stress tolerance. Photosynthetica 38: 171-186.

Zhang JZ, Creelman RA, Zhu JK (2004) From laboratory to field. Using information from Arabidopsis to engineer salt, cold, and drought tolerance in crops. Plant Physiology 135: 615-621. 